\title{
OSOBOWE NOMINA AGENTIS NA BIAŁOSTOCCZYŹNIE W BADANIACH PROFESORA MICHAEA SAJEWICZA
}

\author{
AgnieszKa Goral \\ Maria Curie-Sklodowska University in Lublin
}

\begin{abstract}
PERSONAL NOMINA AGENTIS FROM THE BIALYSTOK REGION IN THE WORKS OF PROF. MICHAL SAJEWICZ. The article presents the achievements of Professor Michał Sajewicz in the field of research on the category of personal nomina agentis on the Polish-Belarusian border (the Bialystok region in Poland). The source materials consist of Sajewicz's publications dedicated to the functioning and derivation of masculine-personal names with a suffixal word-formation in central and southern parts of the Bialystok region, including monographs and scholarly articles published, among others, in journals such as Rozprawy Slawistyczne, Slavia Orientalis, Etnolingwistyka, Roczniki Humanistyczne KUL, Acta Albaruthenica, Acta Polono-Ruthenica, Belarusica-Albaruthenica. The analysis is based on the descriptive method, while the publications are analyzed in a chronological order (from the earliest issued). The study proves that the Lublin researcher has contributed significantly to the enrichment of the knowledge about the state of the southernmost dialects located in the Bialystok region, belonging to the south-western Belarusian dialect. In the scope of analysis, he revealed that the process of derivation does not differ significantly from the wording of the noun in the standard Belarusian language.
\end{abstract}

Keywords: Michał Sajewicz, nomina agentis, Bialystok region dialects, Belarusian dialects, dialectal word-formation

Celem artykułu jest analiza wkładu naukowego profesora Michała Sajewicza w badania nad kategorią osobowych nazw wykonawców czynności (nomina agentis) na pograniczu polsko-białoruskim. Jako baza materiałowa zostały wykorzystane publikacje slawisty, obejmujące monografie oraz artykuły naukowe (zob. Sources), wydane między innymi w takich czasopismach, jak Rozprawy Slawistyczne, Slavia Orientalis, Etnolingwistyka, Roczniki Humanistyczne KUL, Acta Albaruthenica, Acta Polono-Ruthenica, Biełarusika-Albaruthenica. Analizowane materiały poświęcone są funkcjonowaniu i derywacji nazw męskoosobowych z sufiksalnym formantem słowotwórczym. Nazwy te odnotowano podczas eksploracji terenowych prowadzonych w latach 1974-79 oraz 1988-96 w kilkudziesięciu wsiach położonych na Białostocczyźnie środkowej i południowej. 
Prof. dr hab. Michał Sajewicz jest jednym z najbardziej znanych i zasłużonych slawistów-dialektologów naszych czasów. Swoje losy związał z Uniwersytetem Marii Curie-Skłodowskiej w Lublinie, ale pochodzi z Białostocczyzny. Urodził się 15 czerwca 1949 r. w Lewkowie Nowym w województwie podlaskim (powiat hajnowski, gmina Narewka). Edukację rozpoczął w 1956 r., początkowo w szkole podstawowej w Lewkowie Starym, następnie - w 1963 r. - w Liceum Ogólnokształcącym nr 10 z językiem białoruskim w Hajnówce. W 1967 r. podjął studia wyższe na filologii rosyjskiej na UMCS w Lublinie. Pracę magisterską pt. Gwara ruska okolic Narewki w pow. hajnowskim (fonetyka - fleksja) napisał pod kierunkiem znanego slawisty, prof. dr hab. Michała Łesiowa. W czerwcu 1972 r. Michał Sajewicz uzyskał tytuł zawodowy magistra filologii rosyjskiej, a od 1 października $1972 \mathrm{r}$. podjął pracę w Zakładzie Filologii Rosyjskiej UMCS. Jako młody asystent kontynuował badania nad słowotwórstwem rzeczowników w gwarach białoruskich Białostocczyzny.

W 1983 r. Michał Sajewicz uzyskał stopień doktora nauk humanistycznych na podstawie liczącej 624 strony rozprawy doktorskiej pt. Słowotwórstwo rzeczowników w gwarach wschodniosłowiańskich na terenie byłego powiatu hajnowskiego. Następnie kontynuował badania nad słowotwórstwem rzeczowników w gwarach białoruskich Białostocczyzny. Równolegle z eksploracją terenową materiału gwarowego prowadził prace nad rozprawą habilitacyjną poświęconą nazwom subiektów w nadnarwiańskich gwarach białoruskich Białostocczyzny, a ich zwieńczeniem była wydana w 2002 r. monografia pt. Derywacja sufiksalna osobowych nazw subiektów w nadnarwiańskich gwarach białoruskich Białostocczyzny. Deverbativa, deadiectiva, przedłożona w styczniu 2003 r. Radzie Wydziału Humanistycznego UMCS jako rozprawa habilitacyjna.

Po uzyskaniu stopnia doktora habilitowanego w zakresie językoznawstwa słowiańskiego badania Michała Sajewicza koncentrowały się głównie wokół takich zagadnień, jak: słowotwórstwo rzeczowników w gwarach wschodniosłowiańskich Białostocczyzny ze szczególnym uwzględnieniem nadnarwiańskich gwar białoruskich, antroponimia polsko-białorusko-ukraińskiego pogranicza językowego, zróżnicowanie etniczne, wyznaniowe i językowe mieszkańców Białostocczyzny wschodniej, Białoruś - kraj między Wschodem i Zachodem (przeszłość i współczesność).

Najwięcej publikacji M. Sajewicz poświęcił słowotwórstwu rzeczowników osobowych z formantem sufiksalnym na pograniczu polsko-białoruskim na Białostocczyźnie. Badania tej problematyki prowadził ponad dwadzieścia lat, a ich wyniki analizował przy wykorzystaniu różnorodnych narzędzi (między innymi kwestionariuszy do badań gwarowych, nagrań rozmów z informatorami, źródeł archiwalnych, baz internetowych), ponadto w publikacjach naukowych odwoływał się do osiągnięć najznakomitszych polskich i europejskich slawistów (zarówno językoznawców, jak i badaczy kultury), między innymi E. 
Smułkowej (Smułkowa 1968), M. Kondratiuka (Kondratiuk 1964, 1976, 1981, 1995), M. Tichoniuka (Tichoniuk 1988), M. Łesiowa (Lesiow 1994, 2000), S. Gali (Gala 1975, 1981), S. Glinki (Glinka 1960), E. Mironowicza (Mironowicz 1993), A. Leszczyńskiego (Leszczynski 1989), A. Sadowskiego (Sadowski 1991), J. Wiśniewskiego (Wisniewski 1964a, 1964b, 1977a, 1977b, 1980), W. Kuraszkiewicza (Kuraszkiewicz 1939, 1969), K. Dejny (Dejna 1973, 1976, 1991), a także A. Ziemskiej (Zemskaya 1992), W. Łopatina (Lopatin 1977), I. Ułuchanowa (Uluchanov 1977), L. Szakuna (Shakun 1978), P. Sciacki (Sciacko 1970).

Pionierski artykuł poświęcony kategorii osobowych nomina agentis na Białostocczyźnie ukazał się w 1977 r. i nosił tytuł Dewerbalne "nomina agentis" w gwarach wschodniosłowiańskich okolic Puszczy Białowieskiej na terenie PRL (Sajewicz 1977). Autor dowodził w nim, że w badanych gwarach najbardziej produktywny jest typ słowotwórczy z formantem -un, poświadczony w 33 nacechowanych emocjonalnie derywatach dewerbalnych, por. bałbatun ' 'ten, kto bełkocze, tj. mówi niewyraźnie', brachun 'ten, kto mówi dużo i bez sensu', dryhun 'ten, kto drży, na przykład z powodu choroby układu nerwowego' (Sajewicz 1977: 203). Do produktywnych badacz zaliczył także derywaty osobowe z sufiksami -ło (22 derywaty: por. bl'uskało 'ten kto mruga oczami', brontało 'ten, kto włóczy się bez celu', harkało 'ten, kto jest niedelikatny w mówieniu i byciu'), -nik (por. kal'adnik 'ten, kto kolęduje, kolędnik', kirauninik 'ten, kto kieruje (czymś)'), do grupy derywatów o średniej produktywności - typy słowotwórcze nazw działacza między innymi z formantem -ač (por. charkač 'ten, kto chrząka', nahaniač 'ten, kto nagania zwierzynę podczas polowania'), z kolei do najmniej produktywnych - z formantami -ak (por. spiwak 'ten, kto śpiewa', wazak 'ten, kto wozi (coś)'), -ar (por. buntar 'ten, kto się buntuje (przeciwko czemuś)', handl'ar 'ten, kto handluje (czymś)', -ciel (por. učyciel 'ten, kto uczy (czegoś)'), -ant (por. praktykant).

Na przełomie lat 8o. i 9o. ubiegłego wieku M. Sajewicz kontynuował badania poświęcone derywacji sufiksalnej kategorii osobowych nomina agentis w gwarach białoruskich na Białostocczyźnie. Istotne ustalenia dotyczące interesującej go problematyki poczynił między innymi w artykułach Dublety strukturalne w kategorii dewerbalnych „nomina agentis” w gwarach pogranicza białorusko-ukraińskiego na Białostocczyźnie (Sajewicz 1989), Produktywne typy słowotwórcze dewerbalnych nazw agentywnych w gwarach białoruskich okolic Narewki i Białowieży na Białostocczyźnie (Sajewicz 1990) oraz Dewerbalne „nomina agentis” z formantami „-ło”, „-un” w gwarach białoruskich okolic Narewki na Białostocczyźnie (Sajewicz 1995a).

Artykuł Dublety strukturalne w kategorii dewerbalnych „nomina agentis” w gwarach pogranicza białorusko-ukraińskiego na Białostocczyźnie (Sajewicz 1989), badacz poświęcił

1 Tu i dalej: zastosowano uproszczony zapis rzeczowników gwarowych. 
synonimom słowotwórczym. Dokonał zestawienia i analizy około tysiąca dewerbalnych synonimicznych jednostek leksykalnych, zanotowanych w peryferyjnych gwarach białoruskich okolic Narewki i Białowieży. Lubelski slawista wykazał, że na badanym obszarze najdłuższe szeregi synonimiczne tworzą derywaty ekspresywne, zwłaszcza nacechowane pejoratywnie. Ustalił ponadto, że dublety najczęściej występują pomiędzy formantami wykazującymi identyczną lub zbliżoną dystrybucję, a w szeregach synonimicznych za najbardziej produktywne uznał formanty słowotwórcze -ło, -un oraz -ač.

W 1990 r. M. Sajewicz opublikował artykuł pt. Produktywne typy słowotwórcze dewerbalnych nazw agentywnych w gwarach białoruskich okolic Narewki i Białowieży na Białostocczyźnie (Sajewicz 1990). Autor przeanalizował w nim 1140 dewerbalnych nazw agentywnych (w tym 835 nomina agentis oraz 305 nomina instrumenti), utworzonych przy pomocy 159 sufiksalnych formantów słowotwórczych. Analiza wykazała, że w urabianiu odczasownikowych nazw działacza w badanych gwarach uczestniczy 121 formantów, zaś nazw narzędzi - 69, przy czym za pomocą 31 formantów utworzono zarówno nazwy działacza, jak i nazwy narzędzi. Wśród nazw osobowych do najliczniej reprezentowanych badacz zaliczył typy słowotwórcze z sufiksami -ca (por. k'irouxca, marnatrauxca), -ec (por. kas'ec, kup'ec), -lec (por. rydal'ec, sk'ital'ec), -lnica (por. padbiral'ńica, vyšyval'nica), -uxa (por. rahatuxa, šaptuxa), -aka (por. čytaka, sp'ivaka), -čyk (por. danoščyk, paravoščyk) -c'el' (por. mučyc'el', paručyc'el'), -ar (por. handl'ar, p’ekar). Pozostałe formanty (z wyjątkiem sufiksu -dło, który urabiał wyłącznie nazwy narzędzi, por. kavadło) tworzyły zarówno nazwy osobowe, jak i nieosobowe, a największą produktywność przejawiały typy słowotwórcze z formantami -ło (por. duło, krapiło), -un (por. havarun, svistun), -auي ka (por. dyndauxka, dyxaukka), -nik (por. kal'adńik, padl'izńik), -ač (por. braxač, matač), -ńica (por. čarauńnica, šatkauńnica), -ka (por. płačka, trutka), -ačka (por. kapačka, s’ikačka), -arka (por. pl'atkarka, sušarka), -uška (por. havaruška, karmuška).

Najbardziej produktywnym typom słowotwórczym w kategorii osobowych nomina agentis M. Sajewicz poświęcił artykuł Dewerbalne nomina agentis z formantami „-ło”, „-un” w gwarach białoruskich okolic Narewki i Białowieży na Białostocczyźnie (1995). Prezentowana w nim analiza powstała na bazie materiału zebranego w latach 1974-1979 we wsiach Łuka, Siemianówka, Lewkowo Stare, Lewkowo Nowe, Eliaszuki, Kapitańszczyzna, Narewka, Bernadzki Most, Skupowo, Masiewo, Białowieża, Pogorzelce i Teremiski. Badacz opisał łącznie 435 derywatów. Na podstawie przeprowadzonej analizy udowodnił, że obydwa sufiksy mają charakter typowo gwarowy i cechuje je wysoka produktywność zarówno w gwarach białoruskich, jak i ukraińskich.

Na początku XXI w. M. Sajewicz kontynuował badania nad kategorią nomina agentis w gwarach Białostocczyzny, a szczególną uwagę poświęcił osobowym nomina agentis 
z sufiksalnymi formantami słowotwórczymi: -ło, un (Sajewicz 2000c, 2000a, 2007), -nik (Sajewicz 2003, por. Sajewicz 2000c, 2000a), -ač (Sajewicz 2000a, 2005, 2007), -ak (2006).

W artykułach Suffiksalnoje słowoobrazowanije otgłagolnych nazwanij subjektow diejstwij w biełorusskich goworach wierchniego tieczenija rieki Nariew w biełostokskom riegionie (Polsza) (200o), Desubstantywne osobowe nazwy subiektów właściwości z formantem sufiksalnym w nadnarwiańskich gwarach białoruskich Białostocczyzny (200oa) oraz Odczasownikowe nazwy subiektów z formantami „-ło”, „-un”, „-ač” w nadnarwiańskich gwarach Białostocczyzny (2007) slawista poszerzył analizowany materiał o jednostki zebrane w latach 1988-1996, jednakże ich opis ograniczył do nazw motywowanych czasownikami oznaczającymi działalność aparatu artykulacyjnego człowieka. Wykazał, że sufiksy -ło, -un, -ač posiadają wysoki potencjał w derywacji sufiksalnych nazw osobowych i stanowią $62 \%$ ogółu rejestru formantów słowotwórczych aktywnych w opisywanych gwarach (Sajewicz 2007). Szczegółowa analiza semantyczna pozwoliła z kolei ustalić, że derywaty z sufiksami -ło, -un, -ač z reguły wyrażają lekceważący, niechętny lub pogardliwy stosunek mówiącego do osoby, która wykonuje czynność nazwaną podstawą słowotwórczą.

Artykuł Z metodologii badań nad słowotwórstwem peryferyjnych gwar białoruskich Białostocczyzny (Sajewicz 2001) autor poświęcił z kolei desubstantywnym osobowym nomina agentis. Badacz wykazał, że opisywaną kategorię cechuje wielość możliwych ról i kombinacji komunikowanych przez podstawę słowotwórczą i formant: agens i obiekt, agens i rezultat, agens i instrument, agens i sposób wykonywania czynności, agens i czas wykonywania czynności. Ich analiza pozwoliła na wyodrębnienie szesnastu grup derywatów: odobiektowe nazwy subiektów, odrezultatywne nazwy subiektów, odmateriałowe nazwy subiektów, odmiejscowe nazwy agentywne, odmiejscowe nazwy nieagentywne (nazwy mieszkańców), nazwy posiadaczy, nazwy amatorów, nazwy zwolenników idei i poglądów, nazwy subiektów właściwości, nazwy uczestników zdarzeń, odsposobowe nazwy subiektów, nazwy elementów zbiorów, nazwy symilatywne, nazwy pokrewieństwa, nazwy temporalne $^{1}$ (Sajewicz 2001: 91).

Najpełniejszą analizę osobowych nomina agentis w nadnarwiańskich gwarach białoruskich Białostocczyzny M. Sajewicz przedstawił w monografiach: Derywacja sufiksalna osobowych nazw subiektów w nadnarwiańskich gwarach białoruskich Białostocczyzny. Deverbativa, deadiectiva (Sajewicz 2002) oraz Odczasownikowe pejoratywne nazwy subiektów

1 W artykule $Z$ metodologii badań... M. Sajewicz zawarł również ważne postulaty metodologiczne, a za najważniejszy z nich uznał zasadę kompleksowego opisu systemu słowotwórczego danej gwary bądź poszczególnych jej elementów w obrębie typów lub kategorii słowotwórczych (Sajewicz 2001: 99). 
z formantem sufiksalnym w gwarach białoruskich okolic Lewkowa Starego na Białostocczyźnie (Sajewicz 2019).

Punktem wyjścia w przedłożonej w 2003 r. jako rozprawa habilitacyjna monografii Derywacja sufiksalna osobowych nazw subiektów w nadnarwiańskich gwarach białoruskich Białostocczyzny. Deverbativa, deadiectiva była ogólna charakterystyka terenu badań w aspekcie historycznym, socjologicznym, a także lingwistycznym. W pracy autor usystematyzował opis systemu fonologicznego najdalej na południe położonych gwar na terenie Białostocczyzny, należących do południowo-zachodniego dialektu języka białoruskiego, a w części praktycznej opisał dewerbalne i deadiektywne nomina agentis (2630 derywatów), tworzące odpowiednio 81 i 56 typów słowotwórczych. Typy te badacz podzielił pod względem liczebności na sześć grup: typy o bardzo wysokiej liczebności (ponad 100 derywatów), wysokiej (51-100), znacznej (21-50), średniej (11-20), niskiej (6-10) oraz bardzo niskiej (2-5). Ustalił, że w badanych gwarach wśród rzeczowników utworzonych od podstaw czasownika największą liczbę stanowią nazwy z formantami słowotwórczymi -ło (340 przykładów, por. brontało, cmokało), -ač (337, por. adbirač, trapač), -un (247, por. braskatun, brykun), a także między innymi -nik (93), -auxka (74), -lnik (58), -ak (46), -c’el (44), -aka (37), -čyk (32), -lščyk (31), -ca (30), -ščyk (30), -niec (26), - ar (26), -ec (25). Z kolei w grupie derywatów deadiektywnych najliczniejszy zbiór stanowiły nazwy subiektów z formantami -ik (130 nazw, por. dabradušnik, kalisnik), -ec (102, por. bajazlivec, zazdronec), -ač (81, por. basač, tysač), -ak (8o, por. bas'ak, prasc'iak), a także -un (39), -ota (26), -eča (18).

Wnioski zawarte w monografii Derywacja sufiksalna osobowych nazw subiektów w nadnarwiańskich gwarach białoruskich Białostocczyzny. Deverbativa, deadiectiva stały się podstawą dalszych badań nad kategorią osobowych nomina agentis na pograniczu polsko-białoruskim. Badania te M. Sajewicz prowadził przez kolejne kilkanaście lat, a ich rezultaty opublikował w rozprawie Odczasownikowe pejoratywne nazwy subiektów z formantem sufiksalnym w gwarach białoruskich okolic Lewkowa Starego na Białostocczyźnie (Sajewicz 2019). Monografia ta powstała na kanwie materiału gwarowego, obejmującego 1365 nazw męskoosobowych nacechowanych pejoratywnie nomina agentis, zanotowanych podczas eksploracji terenowych w okolicach Lewkowa Starego na Białostocczyźnie.

Materiał został pogrupowany według 84 typów słowotwórczych należących do kategorii dewerbalnych nazw subiektów z formantem sufiksalnym. Analizowane rzeczowniki stanowiły w zdecydowanej większości derywaty określające męskoosobowych wykonawców czynności używane w znaczeniu skłonnościowym, por. ašukaniec, bałbatun, drymko, kanbinator, padmanščyk, rydalec, turzač, vyjec. Badanie dowiodło, że w derywacji gwarowych nomina agentis najwyższą frekwencję posiadają leksemy z formantami słowotwórczymi -ło (326), -ač (239), -un (210), -nik (59), - aukka (59), -aka (38), -ak (36), -ciel (23), -niec (22). 
W rozprawie M. Sajewicz dowiódł, że w badanych gwarach ponad 70\% rzeczowników osobowych należących do kategorii nomina agentis posiada ujemne nacechowanie stylistyczne. W nawiązaniu do prac S. Grabiasa (Grabias 1980), slawista wyróżnił cztery grupy pejoratywów: nazwy urobione neutralnym formantem słowotwórczym od nacechowanej ujemnie podstawy czasownikowej (por. dakučnik, narykalnik), nazwy urobione pejoratywnym formantem słowotwórczym od neutralnej stylistycznie podstawy czasownikowej (por. pisaka, spivaka), nazwy urobione pejoratywnym formantem słowotwórczym od nacechowanej ujemnie podstawy czasownikowej (por. rydal, ryksa), nazwy urobione melioratywnym formantem słowotwórczym od nacechowanej ujemnie podstawy czasownikowej (por. łazik, psocik). Badane derywaty ekspresywne wyrażały - w ujęciu M. Sajewicza - różnorodne emocje (niedowierzanie, niezadowolenie, lekceważenie, dystans, zniecierpliwienie, ironię, złośliwość, zazdrość, pogardę), a ich klasyfikacja semantyczna opierała się na analizie kontekstowej, a więc użyciu w konkretnym tekście.

Dorobek naukowy profesora Michała Sajewicza dowodzi, że lubelski badacz w sposób znaczący przyczynił się do wzbogacenia wiedzy na temat kategorii nomina agentis w gwarach białoruskich na pograniczu polsko-białoruskim. Usystematyzował opis systemu fonologicznego najdalej na południe położonych gwar na terenie Białostocczyzny, należących do południowo-zachodniego dialektu języka białoruskiego. Wykazał, że w zakresie badanej kategorii nazw proces derywacji nie różni się zasadniczo od słowotwórstwa rzeczownika w literackiej odmianie języka. Rejestr typów słowotwórczych pozwolił badaczowi na wyodrębnienie formantów słowotwórczych występujących w badanych gwarach, ze szczególnym uwzględnieniem sufiksów typowo gwarowych (-un, -ło). W publikacjach naukowych derywację osobowych nazw subiektów autor zaprezentował na tle innych gwar, w pierwszym rzędzie białoruskich, częściowo ukraińskich, w mniejszym zaś stopniu polskich, jak również w porównaniu z białoruskim, ukraińskim i polskim językiem literackim, przy wykorzystaniu osiągnięć polskiej i europejskiej dialektologii.

W badaniach kategorii nomina agentis w gwarach nadnarwiańskich Białostocczyzny M. Sajewicz wiele miejsca poświęcił semantyce analizowanych derywatów. Dowiódł, że nazwy subiektów czynności należą do leksyki ekspresywnej, z reguły nazywającej człowieka ze względu na cechy charakterystyczne (na przykład sposób mówienia lub poruszania się, wykonywaną czynność). Prawie wszystkie derywaty cechuje nacechowanie pejoratywne, ponadto niektóre określają człowieka w sposób lekceważący, ironiczny lub żartobliwy.

W analizowanych materiałach uwagę zwracają partie dotyczące zagadnień bezpośrednio nie związanych z opisywanym tematem, lecz pozwalające na pełniejsze omówienie tematu: zarówno w monografiach, jak i licznych artykułach naukowych opis sytuacji językowej na Białostocczyźnie jest powiązany z faktami historycznymi (historia osadnictwa 
na badanym terenie), socjologicznymi (struktura narodowościowa i społeczna badanych miejscowości, kwestie tożsamościowe), religijnymi (przynależność do konfesji), a nawet czynnikami geograficznymi (ukształtowanie terenu, naturalne granice między badanymi miejscowościami). Uwzględnienie szerokiego tła historycznego i społecznego, a także kulturowego pozwoliło M. Sajewiczowi na prezentację zagadnień powiązanych ze sobą i wzajemnie uwarunkowanych, wpisujących się w szeroki kontekst kulturowy.

Uwzględnienie tak szerokiego kontekstu w badaniach gwarowych można uznać za istotny postulat prac naukowych M. Sajewicza. Równie ważne wydają się propozycje metodologiczne slawisty: uwzględnienie w większym niż dotychczas stopniu teorii słowotwórstwa synchronicznego języków słowiańskich oraz prowadzonych współcześnie w polskich i białoruskich ośrodkach naukowych kierunków badań w zakresie słowotwórstwa, dążenie do eksploracji materiału w możliwie blisko leżących względem siebie miejscowościach w celu uzyskania kompletnej i zweryfikowanej przez dużą liczbę informatorów bazy materiałowej, wykorzystanie wielości źródeł (wywiadów, wypisów ze źródeł pisanych: prac naukowych oraz dokumentów użytkowych: metryk, aktów prawnych, świadectw, wykorzystanie internetowych baz danych), stosowanie różnorodnych metod (kwestionariuszy do badań terenowych, metody zapisu na nośnikach elektronicznych).

Dorobek naukowy M. Sajewicza w zakresie badań nad kategorią nomina agentis w gwarach wschodniosłowiańskich Białostocczyzny nie tylko wypełnia lukę w dotychczasowych opracowaniach z tego zakresu, ale także wskazuje innym uczonym nowe kierunki badawcze, zwłaszcza w zakresie gwarowych analiz porównawczych. Opracowanie nowoczesnych słowników gwarowych opartych na materiałach z różnych regionów Polski wydaje się zadaniem wymagającym kompleksowych badań prowadzonych przez zespoły badawcze skupione w różnych ośrodkach naukowych. Prace o takim charakterze miałyby istotne znaczenie dla zachowania i utrwalenia lokalnego dziedzictwa kulturowego na współczesnym etapie rozwoju. 


\section{REFERENCES}

\section{Sources:}

Sajewicz 1977: Sajewicz, Michal. „Dewerbalne nomina agentis w gwarach wschodnioslowianskich okolic Puszczy Bialowieskiej na terenie PRL." Acta Universitatis Palackianae Olomucensis. Philologica, no 40 (1977): 201-212. [In Polish: Sajewicz, Michał. „Dewerbalne nomina agentis w gwarach wschodniosłowiańskich okolic Puszczy Białowieskiej na terenie PRL." Acta Universitatis Palackianae Olomucensis. Philologica, no 40 (1977): 201-212.]

Sajewicz \& Czyzewski 1979: Sajewicz, Michal \& Czyzewski, Feliks. „Zroznicowanie slownictwa rolniczego w kilku gwarach wschodnioslowianskich na polsko-bialorusko-ukrainskim pograniczu jezykowym." In: Smoczynski, Pawel, ed. Slavica Lublinensia et Olomucensia: 151-170. Lublin: UMCS University Press, 1979. [In Polish: Sajewicz, Michał \& Czyżewski, Feliks. „Zróżnicowanie słownictwa rolniczego w kilku gwarach wschodniosłowiańskich na polsko-białorusko-ukraińskim pograniczu językowym." W: Smoczyński, Paweł, red. Slavica Lublinensia et Olomucensia: 151-17o. Lublin: Wyd. UMCS, 1979.]

Sajewicz 1986: Sajewicz, Michal. „Ze studiow nad gwarami bialoruskimi Bialostocczyzny na poludnie od Narwi.” Rozprawy Slawistyczne, no 1 (1986): 239-249. [In Polish: Sajewicz, Michał. „Ze studiów nad gwarami białoruskimi Białostocczyzny na południe od Narwi." Rozprawy Slawistyczne, no 1 (1986): 239-249.]

Sajewicz 1989: Sajewicz, Michal. „Dublety strukturalne w kategorii dewerbalnych nomina agentis w gwarach z pogranicza bialorusko-ukrainskiego na Bialostocczyznie." Rozprawy Slawistyczne, no 4 (1989): 265-271. [In Polish: Sajewicz, Michał. „Dublety strukturalne w kategorii dewerbalnych nomina agentis w gwarach z pogranicza białorusko-ukraińskiego na Białostocczyźnie." Rozprawy Slawistyczne, no 4 (1989): 265-271.]

Sajewicz 1990: Sajewicz, Michal. „Produktywne typy słowotworcze dewerbalnych nazw agentywnych w gwarach bialoruskich okolic Narewki i Bialowiezy na Białostocczyznie." Slavia Orientalis, no 3-4 (1990): 397-408. [In Polish: Sajewicz, Michał. „Produktywne typy słowotwórcze dewerbalnych nazw agentywnych w gwarach białoruskich okolic Narewki i Białowieży na Białostocczyźnie.” Slavia Orientalis, no 3-4 (1990): 397-408.]

Sajewicz 1992: Sajewicz, Michal. „Nasza mowa prosta, czyli o zagadnieniu bialorusko-ukrainskiej granicy jezykowej na Bialostocczyznie.” Nad Buhom i Narwoju, no 3 (4 / 1992): 15-19. [In Polish: Sajewicz, Michał. „Nasza mowa prosta, czyli o zagadnieniu białorusko-ukraińskiej granicy językowej na Białostocczyźnie.” Nad Buhom i Narwoju, no 3 (4): 15-19.]

Sajewicz 1995a: Sajewicz, Michal. „Dewerbalne nomina agentis z formantami -to, -un w gwarach bialoruskich okolic Narewki na Bialostocczyznie." Rozprawy Slawistyczne, no 10: 197-210. [In Polish: Sajewicz, Michał. „Dewerbalne nomina agentis z formantami -to, -un w gwarach białoruskich okolic Narewki na Białostocczyźnie." Rozprawy Slawistyczne, no 10: 197-210.]

Sajewicz 1995b: Sajewicz, Michal. „Ujaulennie maloj radzimy u bielaruskamounych wiaskowych supolnasciach na Bielastoczczynie.” Wieści Biełaruskaha dziarżaunaha uniwiersiteta. Sieryja 4, no, 2: 44-48. [In Belarusian: Sajewicz, Michał. „Ujaulennie małoj radzimy u biełaruskamounych 
wiaskowych supolnasciach na Biełastoczczynie." Wieści Biełaruskaha dziarżaunaha uniwiersiteta. Sieryja 4, no, 2: 44-48.]

Sajewicz 20ooa: Sajewicz, Michal. „Desubstantywne osobowe nazwy subiektow wlasciwosci z formantem sufiksalnym w nadnarwianskich gwarach bialoruskich Bialostocczyzny." Acta Polono-Ruthenica, no 8 (2000): 235-264. [In Polish: Sajewicz, Michał. „Desubstantywne osobowe nazwy subiektów właściwości z formantem sufiksalnym w nadnarwiańskich gwarach białoruskich Białostocczyzny”. Acta Polono-Ruthenica, no 8 (2000): 235-264.]

Sajewicz 2ooob: Sajewicz, Michal. „Zroznicowanie etniczne, wyznaniowe i jezykowe Bialostocczyzny w swietle dotychczasowych badan naukowych oraz w oczach mieszkancow tego regionu." Biełarusika - Albaruthenica, no 15 (2000): 68-78. [In Polish: Sajewicz, Michał. „Zróżnicowanie etniczne, wyznaniowe i językowe Białostocczyzny w świetle dotychczasowych badań naukowych oraz w oczach mieszkańców tego regionu." Biełarusika - Albaruthenica, no 15 (2000): 68-78.]

Sajewicz 2oooc: Sajewicz, Michal. „Suffiksalnoje slowoobrazowanije otglagolnych nazwanij subjektow diejstwij w bielorusskich goworach wierchniego tieczenija rieki Nariew w bielostokskom riegionie (Polsza)." In: Warchol, Stefan, ed. 3rd International Congress of Dialectologists and Geolinguists. Abstract Book: 142-143. Lublin: UMCS University Press, 2000. [In Russian: Sajewicz, Michał. „Suffiksalnoje słowoobrazowanije otgłagolnych nazwanij subjektow diejstwij w biełorusskich goworach wierchniego tieczenija rieki Nariew w biełostokskom riegionie (Polsza)." W: Warchol, Stefan, red. 3rd International Congress of Dialectologists and Geolinguists. Abstract Book: 142-143. Lublin: Wydawnictwo UMCS, 200o.]

Sajewicz 20o1: Sajewicz, Michal. „Z metodologii badan nad slowotworstwem peryferyjnych gwar bialoruskich Bialostocczyzny”. W: Czyzewski, Feliks, ed. Język i kultura na pograniczu polskoukraińsko-białoruskim: 77-104. Lublin: Wydawnictwo Instytutu Europy Srodkowo-Wschodniej, 2001. [In Polish: Sajewicz, Michał. „Z metodologii badań nad słowotwórstwem peryferyjnych gwar białoruskich Białostocczyzny." W: Czyżewski, Feliks, red. Język i kultura na pograniczu polskoukraińsko-białoruskim: 77-104. Lublin: Wydawnictwo Instytutu Europy Środkowo-Wschodniej, 2001.]

Sajewicz 2002: Sajewicz, Michal. Derywacja sufiksalna osobowych nazw subiektow w nadnarwianskich gwarach bialoruskich Bialostocczyzny. Deverbativa, deadiectiva. Lublin: UMCS University Press, 2002. [In Polish: Sajewicz, Michał. Derywacja sufiksalna osobowych nazw subiektów w nadnarwiańskich gwarach białoruskich Białostocczyzny. Deverbativa, deadiectiva. Lublin: Wyd. UMCS, 2002.]

Sajewicz 2005: Sajewicz, Michal. „Deadiektive Personal Nomina Subiecti with a Formant -ač in Belarusian Dialects in Narewka Area of the Bialystok Region." Roczniki Humanistyczne, no 53 (7 / 2005): 161-176. [In Polish: Sajewicz, Michał. „Deadiektywne osobowe nomina subiecti z formantem słowotwórczym - ač w gwarach białoruskich okolic Narewki na Białostocczyźnie." Roczniki Humanistyczne, no 53 ( 7 / 2005): 161-176.]

Sajewicz 2006: Sajewicz, Michal. „Personal Names of Subjects with a Formant - ač in Belarusian Dialects in Narewka Area of the Bialystok Region." In: Citko, Lilia \& Siegien, Bazyli, eds. Gwary i onomastyka pogranicza polsko-wschodnioslowianskiego i slowiansko-baltyckiego: 293-310. University of Bialystok Press, 2006. [In Polish: Sajewicz, Michał. „Osobowe nazwy subiektów z formantem słowotwórczym - $a k \mathrm{w}$ nadnarwiańskich gwarach białoruskich Białostocczyzny." W: Citko, Lilia \& Siegień, Bazyli, red. Gwary i onomastyka pogranicza polskowschodniosłowiańskiego i słowiańsko-bałtyckiego: 293-310. Białystok: Wyd. Uniwersytetu w Białymstoku, 2006.] 
Sajewicz 2007: Sajewicz, Michal. „Odczasownikowe nazwy subiektow z formantami -ło, -un, -ač w nadnarwianskich gwarach bialoruskich Bialostocczyzny." Acta Albaruthenica, no 7 (2007): 246-262. [In Polish: Sajewicz, Michał. „Odczasownikowe nazwy subiektów z formantami -ło, -un, -ač w nadnarwiańskich gwarach białoruskich Białostocczyzny." Acta Albaruthenica, no 7 (2007): 246-262.]

Sajewicz 2019: Sajewicz, Michal. Dewerbal Pejorative Names of Subjects with Suffixal Formants in the Peripherial Belarusian Dialects of the Lewkowo Stare Area in the Bialystok Region. Lublin: UMCS University Press, 2019. [In Polish: Sajewicz, Michał. Odczasownikowe pejoratywne nazwy subiektów z formantem sufiksalnym w gwarach białoruskich okolic Lewkowa Starego na Białostocczyźnie. Lublin: Wyd. UMCS, 2019.]

\section{Works Cited:}

Dejna 1973: Dejna, Karol. Polish Dialects. Wroclaw: Ossolineum, 1973. [In Polish: Dejna, Karol. Dialekty polskie. Wrocław: Zakład Narodowy im. Ossolińskich, 1973.]

Dejna 1976: Dejna, Karol. „Jezykowa przynaleznosc gwar brzesko-pinskich.” In: Bajor, Kazimierz, ed. Jezyki i literatury wschodnioslowianskie: 13-20. University of Lodz Press, 1976. [In Polish: Dejna, Karol. „Językowa przynależność gwar brzesko-pińskich.” W: Bajor, Kazimierz, red. Języki i literatury wschodniosłowiańskie: 13-20. Łódź: Uniwersytet Łódzki, 1976.]

Dejna 1991: Dejna, Karol. Z zagadnien ewolucji oraz interferencji jezykowej. University of Lodz Press, 1991. [In Polish: Dejna, Karol. Z zagadnień ewolucji oraz interferencji językowej. Uniwersytet Łódzki, 1991.]

Gala 1975: Gala, Slawomir. „Z zagadnien klasyfikacji nazw osobowych.” Rozprawy Komisji Jezykowej LTN, no 21 (1975): 43-55. [In Polish: Gala, Sławomir. „Z zagadnień klasyfikacji nazw osobowych”. Rozprawy Komisji Językowej ŁTN, no 21 (1975): 43-55.]

Gala 1981: Gala, Slawomir. „W sprawie jezykowej klasyfikacji nazw osobowych.” Onomastica, no 26 (1981): 41-51. [In Polish: Gala, Sławomir. „W sprawie językowej klasyfikacji nazw osobowych.” Onomastica, no 26 (1981): 41-51.]

Glinka 1960: Glinka, Stanislaw. „Granica jezykowa i przyklady zroznicowania fonetycznego gwar bialoruskich Bialostocczyzny." Sprawozdania PAN III, no 5 (1960): 39-45. [In Polish: Glinka, Stanisław. „Granica językowa i przykłady zróżnicowania fonetycznego gwar białoruskich Białostocczyzny." Sprawozdania PAN III, no 5 (1960): 39-45.]

Grabias 1980: Grabias, Stanislaw. O ekspresywnosci jezyka. Ekspresja a slowotworstwo. Lublin: UMCS University Press, 1980. [In Polish: Grabias, Stanisław. O ekspresywności języka. Ekspresja a słowotwórstwo. Lublin: Wyd. UMCS, 1980.]

Kondratiuk 1964: Kondratiuk, Michal. „Wokalizm bialorusko-ukrainskich gwar powiatu hajnowskiego." Slavia Orientalis XIII, no 3 (1964):339-356. [In Polish: Kondratiuk, Michał. „Wokalizm białorusko-ukraińskich gwar powiatu hajnowskiego.” Slavia Orientalis XIII, no 3 (1964): 339-356.]

Kondratiuk 1976: Kondratiuk, Michal. „Polsko-bialoruskie zwiazki leksykalne.” Acta Baltico-Slavica, no 10 (1976): 303-312. [In Polish: Kondratiuk, Michał. „Polsko-białoruskie związki leksykalne.” Acta Baltico-Slavica, no 10 (1976): 303-312.]

Kondratiuk 1981: Kondratiuk, Michal. „Badania onomastyczne w regionie bialostockim.” Rocznik Bialostocki, no 15 (1981): 305-323. [In Polish: Kondratiuk, Michał. „Badania onomastyczne w regionie białostockim." Rocznik Białostocki, no 15 (1981): 305-323.] 
Kondratiuk 1995: Kondratiuk, Michal. „O metodologii badan onomastycznych na pograniczu polskowschodnioslowianskim i slowiansko-baltyckim." In: Kondratiuk, Michal, ed. Badania dialektow i onomastyki na pograniczu polsko-wschodnioslowianskim: 195-203. University of Bialystok Press, 1995. [In Polish: Kondratiuk, Michał. „O metodologii badań onomastycznych na pograniczu polskowschodniosłowiańskim i słowiańsko-bałtyckim.” W: Kondratiuk, Michał, red. Badania dialektów i onomastyki na pograniczu polsko-wschodniosłowiańskim: 195-203. Białystok: Uniwersytet w Białymstoku, 1995.]

Kuraszkiewicz 1939: Kuraszkiewcz, Wladyslaw. „Najwazniejsze zjawiska jezykowe ruskie w gwarach miedzy Bugiem i Narwia." Sprawozdania Towarzystwa Naukowego Warszawskiego, no 2 (1939): 104-120. [In Polish: Kuraszkiewicz, Władysław. „Najważniejsze zjawiska językowe ruskie w gwarach między Bugiem i Narwią." Sprawozdania Towarzystwa Naukowego Warszawskiego, no 2 (1939): 104-120.]

Kuraszkiewicz 1969: Kuraszkiewcz, Wladyslaw. „Tendencje bialoruskie i ukrainskie w gwarach okolic Puszczy Bialowieskiej." Acta Baltico-Slavica, no 1 (1969): 247-257. [In Polish: Kuraszkiewicz, Władysław. „Tendencje białoruskie i ukraińskie w gwarach okolic Puszczy Białowieskiej.” Acta Baltico-Slavica, no 1 (1969): 247-257.]

Lesiow 1994: Lesiow, Michal. „Gwary ukrainskie miedzy Bugiem a Narwia.” Bialostocki Przeglad Kresowy, no 2 (1994): 13-15. [In Polish: Łesiów, Michał. „Gwary ukraińskie między Bugiem a Narwią.” Biatostocki Przegląd Kresowy, no 2 (1994): 13-15.]

Lesiow 200o: Lesiow, Michal. „Z antroponimii kresowej na pograniczu jezykowo-etnicznym.” In Manczak-Wohlfeld, Elzbieta, ed. Studia Linguistica in Honorem Stanislai Stachowski: 79-85. Krakow: Jagiellonian University Press, 200o. [In Polish: Łesiów, Michał. „Z antroponimii kresowej na pograniczu językowo-etnicznym." W: Mańczak-Wohlfeld Elżbieta, red. Studia Linguistica in Honorem Stanislai Stachowski: 79-85. Kraków: Wyd. UJ, 200o.]

Leszczynski 1989: Leszczynski, Anatol. „Z dziejow Zydow Podlasia (1487-1795).” Studia Podlaskie, no 2 (1989): 7-24. [In Polish: Leszczyński, Anatol. „Z dziejów Żydów Podlasia (1487-1795).” Studia Podlaskie, no 2 (1989): 7-24.]

Lopatin 1977: Lopatin, Wladimir. Russkaja slowoobrazowatielnaja morfiemika. Moskow: Nauka, 1977. [In Russian: Лопатин, Владимир. Русская словообразовательная морфемика. Москва: Наука, 1977.]

Mironowicz 1993: Mironowicz, Eugeniusz. Bialorusini w Polsce 1944-49. Warsaw: PWN, 1993. [In Polish: Mironowicz, Eugeniusz. Białorusini w Polsce 1944-49. Warszawa: PWN, 1993.]

Sadowski 1991: Sadowski, Andrzej. Narody wielkie i male. Bialorusini w Polsce. Krakow: Jagiellonian University Press, 1991. [In Polish: Sadowski, Andrzej. Narody wielkie i małe. Białorusini w Polsce. Kraków: Wyd. UJ, 1991.]

Sciacko 1970: Sciacko, Pawal. Narodnaja leksika. Minsk: Nawuka i technika, 197o. [In Belarusian: Сцяцко, Павал. Народная лексіка. Мінск: Навука і тэхніка, 197о.]

Shakun 1978: Shakun, Lieu. Slowautwarennie. Minsk: Wysheyshaya shkola, 1978. [In Belarusian: Шакун, Леў. Словаўтварэнне. Мінск: Вышэйшая школа, 1978.]

Smulkowa 1968: Smulkowa, Elzbieta. Slownictwo z zakresu uprawy roli w gwarach wschodniej Bialostocczyzny na tle wschodnioslowianskim. Wroclaw - Warsaw - Krakow: Ossolineum, 1968. [In Polish: Smułkowa, Elżbieta. Stownictwo z zakresu uprawy roli w gwarach wschodniej 
Białostocczyzny na tle wschodniosłowiańskim. Wrocław - Warszawa - Kraków: Zakład Narodowy im. Ossolińskich, 1968.]

Tichoniuk 1988: Tichoniuk, Bazyli. Antroponimia poludniowej Bialostocczyzny w XVI wieku. Opole: Wyzsza Szkola Pedagogiczna im. Powstancow Slaskich, 1988. [In Polish: Tichoniuk, Bazyli. Antroponimia południowej Białostocczyzny w XVI wieku. Opole: Wyższa Szkoła Pedagogiczna im. Powstańców Śląskich, 1988.]

Uluchanov 1977: Uluchanov, Igor. Slowoobrazowatelnaja semantika w russkom jazykie i principy jeje opisanija. Moscow: Nauka, 1977. [In Russian: Улуханов, Игорь. Словообразовательная семантика в русском языке и принципы ее описания. Москва: Наука, 1977.]

Wisniewski 1964a: Wisniewski, Jerzy. „Rozwoj osadnictwa na pograniczu polsko-rusko-litewskim od konca XIV wieku do polowy XVII wieku." Acta Baltico-Slavica, no 1 (1964): 115-135. [In Polish: Wiśniewski, Jerzy. „Rozwój osadnictwa na pograniczu polsko-rusko-litewskim od końca XIV wieku do połowy XVII wieku." Acta Baltico-Slavica, no 1 (1964): 115-135.]

Wisniewski 1964b: Wisniewski, Jerzy. „Zarys dziejow osadnictwa wiejskiego we wschodniej czesci wojewodztwa bialostockiego do polowy XVIII wieku." Naukowy zbornik, no 2 (1964): 3-38. [In Polish: Wiśniewski, Jerzy. „Zarys dziejów osadnictwa wiejskiego we wschodniej części województwa białostockiego do połowy XVIII wieku." Naukowy zbornik, no 2 (1964): 3-38.]

Wisniewski 1977a: Wisniewski, Jerzy. „Tatarzy spod Sokolki i Krynek.” Kontrasty, no 3 (1977): 18-19. [In Polish: Wiśniewski, Jerzy. „Tatarzy spod Sokółki i Krynek.” Kontrasty, no 3 (1977): 18-19.]

Wisniewski 1977b: Wisniewski, Jerzy. „Osadnictwo wschodniej Bialostocczyzny, geneza, rozwoj oraz zroznicowanie i przemiany etniczne." Acta Baltico-Slavica, no 11 (1977): 7-8o. [In Polish: Wiśniewski, Jerzy. „Osadnictwo wschodniej Białostocczyzny, geneza, rozwój oraz zróżnicowanie i przemiany etniczne.” Acta Baltico-Slavica, no 11 (1977): 7-8o.]

Zemskaya 1992: Zemskaya, Yelena. Slowoobrazowanije kak diejatielnost. Moskow: Nauka, 1992. [In Russian: Земская, Елена. Словообразование как деятельность. Москва: Наука, 1992.] 